\title{
BioéthiqueOnline
}

\section{Moral Responsibility in the Context of Prenatal Testing: What can be Expected?}

\section{Marie-Eve Lemoine}

Volume 4, 2015

Reçu : 27 Jan 2015; publié : 30 Mar 2015; éditeurs : Charles Marsan \& Hazar Haidar

URI : https://id.erudit.org/iderudit/1035496ar

DOI : https://doi.org/10.7202/1035496ar

Aller au sommaire du numéro

Éditeur(s)

BioéthiqueOnline

ISSN

1923-2799 (numérique)

Découvrir la revue

Citer cet article

Lemoine, M.-E. (2015). Moral Responsibility in the Context of Prenatal Testing: What can be Expected? BioéthiqueOnline, 4. https://doi.org/10.7202/1035496ar
Résumé de l'article

Des auteurs ont suggérés que l'examen des aspects éthiques et sociaux du test prénatal pouvait être vu comme une responsabilité individuelle des patients, cependant aucun fondement conceptuel n'a été proposé pour appuyer cette thèse. J'avance que la vision de "responsabilité morale comme une vertu" de Candace Cummins Gauthier, développée comme une volonté de concilier les notions d'autonomie et de communauté, fournit ce cadre conceptuel. 


\title{
Moral Responsibility in the Context of Prenatal Testing: What can be Expected?
}

\author{
COMMENTAIRE / COMMENTARY \\ Marie-Eve Lemoine ${ }^{1}$
}

Reçu/Received: 27 Jan 2015

Publié/Published: 30 Mar 2015

Éditeurs/Editors: Charles Marsan \& Hazar Haidar

2015 M-E Lemoine, Creative Commons Attribution 4.0 International License

\section{Résumé}

Des auteurs ont suggérés que l'examen des aspects éthiques et sociaux du test prénatal pouvait être vu comme une responsabilité individuelle des patients, cependant aucun fondement conceptuel n'a été proposé pour appuyer cette thèse. J'avance que la vision de "responsabilité morale comme une vertu" de Candace Cummins Gauthier, développée comme une volonté de concilier les notions d'autonomie et de communauté, fournit ce cadre conceptuel.

\section{Mots clés}

test prénatal, responsabilité morale, société, autonomie, prise de décision

\section{Summary}

Authors have suggested that considering the ethical and social aspects of prenatal testing could be seen as an individual responsibility for patients, but no conceptual grounds have been provided for this thesis. I argue that Candace Cummins Gauthier's account of "moral responsibility as a virtue", developed as an attempt to reconcile notions of autonomy and community, provides such basis.

\section{Keywords}

prenatal testing, moral responsibility, society, autonomy, decision-making

\section{Affiliations des auteurs / Author Affiliations}

${ }^{1}$ Programmes de bioéthique, Département de médecine sociale et préventive, École de santé publique de l'Université de Montréal, Montréal (Québec) Canada

\section{Correspondance / Correspondence}

Marie-Eve Lemoine, marie-eve.lemoine@umontreal.ca

\section{Remerciements}

L'auteure tient à remercier Bryn Williams-Jones, Vardit Ravitsky et Jean-Christophe Bélisle-Pipon. Des bourses des organismes suivants ont permis de soutenir les activités de recherche liées à l'élaboration de ce manuscrit: PEGASUS (PErsonalized Genomics for prenatal Aneuploidy Screening USing maternal blood), IRSPUM (Institut de Recherche en Santé Publique de l'Université de Montréal), CRÉ (Centre de Recherche en Éthique).

\section{Conflit d'intérêts}

Aucune déclaré

\section{Acknowledgements}

The author wishes to thank Bryn Williams-Jones, Vardit Ravitsky and Jean-Christophe Bélisle-Pipon. Scholarships from the following organisations helped support the research activities associated with the development of this manuscript: PEGASUS (PErsonalized Genomics for prenatal Aneuploidy Screening USing maternal blood), IRSPUM (Institut de Recherche en Santé Publique de l'Université de Montréal), CRÉ (Centre de Recherche en Éthique).

\section{Conflicts of Interest}

None to declare

\section{Introduction}

Prenatal testing consists of various diagnostic and screening tools such as blood tests, ultrasounds and amniocentesis. While these tests present various relative strengths and weaknesses with regards to risks, accuracy, access and timeliness, they all share an aim to identify the presence of genetic defects such as trisomy 21, 18 and 13 in a fetus, in order to allow future parents to prepare themselves for the birth of a disabled or sick child, or to terminate the pregnancy. Also shared by all types of prenatal testing are a range of social consequences and ethical dimensions. For instance, while opting for prenatal testing may be an expression of reproductive autonomy at the level of the individual, the cumulative effect of (potentially) all individuals opting for testing and, eventually, for 
termination of an affected pregnancy, can be seen as a form of eugenics [1]. In addition, the mere existence of testing affects the way that we, as a society, view people living with the conditions detected by these tests [2]. Thus, it is argued by critics from the disability rights movement, that testing increases the stigmatization of people affected by disability and their families [3]. Finally, the decrease in prevalence of the conditions detected by prenatal tests, due to high rates of subsequent pregnancy termination (estimated to be around 92\% [4]), is expected to result in a corollary decrease in quality of services and social support for those who do live with these conditions [1]. These ethical and social issues have all been raised in the context of earlier prenatal testing technologies such as amniocentesis, serum and ultrasound markers, and they continue to be relevant in the debate surrounding cell-free fetal DNA testing (cff-DNA), the newest technology in prenatal testing [5].

In a 1995 paper by Nancy Press and Carole H. Browner, the authors suggested that there may exist a social responsibility for prenatal testing patients to consider the social and ethical dimensions of the testing they are about to undergo. This claim was made following interesting empirical findings on the informed consent process experienced by these patients: while social and ethical dimensions were routinely kept out of the information packages, patients did not view this omission as being problematic. Patients' accounts of their decision-making experience were already showing signs that prenatal screening was becoming a routinized practice that patients undergo without engaging in more extensive reflection [2]. Interestingly, this idea of a responsibility of patients to consider the ethical and social dimensions of their choice with regards to prenatal testing has been essentially absent from the bioethics literature. This may be due to the significant emphasis placed on reproductive autonomy in this literature, and to the traditional focus on individual rights within the discourse of autonomy. The aim of this commentary is to revisit Press and Browner's suggestion but through the theoretical lens of moral responsibility. More specifically, I argue that the concept of "moral responsibility as a virtue" developed by Candace Cummins Gauthier [6], provides conceptual grounds for Press and Browner's idea of a responsibility for patients to consider the ethical and social aspects of prenatal testing. I continue with an assessment of the scope and practical implications of this responsibility and conclude with thoughts on the place for this type of responsibility in today's pregnancy care.

\section{Conceptual background and relevance of moral responsibility as a virtue}

Citing communitarian authors such as Alasdair Maclntyre and Michael Sandel, Gauthier starts out by describing the individualistic view of autonomy embedded in our liberal culture. This view is expressed through the extensive emphasis on the language of individual rights, utility, freedom of choice, independence, privacy, informed consent and self-determination. Meanwhile, notions of community, common good, public interest, responsibility, and duties to others are given little attention [6]; and recent bioethics literature on prenatal testing and reproductive autonomy is no exception. While numerous authors have explored the ethical aspects of the newest prenatal testing technology (cellfree fetal DNA testing), emphasis seems to be most often placed on those ethical dimensions that pertain to the individual, such as the need for thorough counselling about risks and benefits, informed consent, social or medical pressure on individuals to test, as well as equity in access and regulation issues pertaining to direct-to-consumer use [1,7-12]. Except from proponents of the disability rights critique, social concerns such as the above-mentioned ones have seemingly been given less attention. Moreover, this tendency translates into clinical practice as recent studies have shown that these issues are not addressed in counselling [13].

In her paper, Gauthier aims to address the "communitarian" challenge to liberal culture by reconciling notions of autonomy and community. The key to this endeavour is the theory of moral responsibility, and more specifically, the concept of "moral responsibility as a virtue". While moral responsibility is most often defined in retrospective terms related to causal responsibility and to the attribution of praise or blame [14], Gauthier's account adds a prospective dimension that operates in the context of decision-making. In addition to the attribution of retrospective/causal responsibility, responsibility as a 
virtue entails that individual decision-making be characterized by care, concern about, and responsiveness to the consequences of one's actions on others and on one's community [6]. For Gauthier, this way of deliberating "leads to an exercise of self-determination that is both responsible and responsive to one's community" [6, p.349]. Applied to the case of prenatal testing, responsibility as a virtue would therefore require that expecting couples consider not only personal reasons for accepting or declining prenatal testing (such as a preference for a "healthy" child or a preference for minimizing medical interventions during pregnancy), but also the societal impacts of testing (such as the reduction in prevalence of specific conditions and the potential exacerbation of stigmatization for people living with these conditions). Hence, I believe that this view is compatible with the articulation of responsibility suggested by Press and Browner.

\section{Scope and practical implications "of moral responsibility as a virtue"; a thought experiment}

However, the scope and implications of this virtue of moral responsibility need to be specified. First, the extent to which one's care, concern and responsiveness must translate into specific action is unclear. For instance, an expecting couple (couple A) may consider the negative effects of the high rates of prenatal testing for Down syndrome on people living with Down syndrome, and feel genuine compassion. This does not mean that a personal preference for a "high achieving" child will not outweigh these considerations and lead the couple to undergo testing and terminate an affected pregnancy. In this case, would the couple be said to have acted following the virtue of moral responsibility? Alternatively, the notions of relationships, community, and the world as potential beneficiaries of our duties of care, concern and responsiveness may conflict amongst each other. For instance, consider another couple in the same situation (couple B). This time, suppose that the decision to undergo testing is not justified by a personal preference but rather by perceived duties to their existing children, e.g., the desire to avoid burdens on existing children, which has been documented as a strong motivation to undergo prenatal testing and terminate affected pregnancies [15]. Similarly, couples may also perceive a duty towards their future child that compels them to undergo testing in order to give birth to the healthiest child possible; in the literature, this is referred to as the principle of procreative beneficence [16]. The couple is still expressing genuine feelings about the impact of their decision on society (i.e., community), but they are prioritizing the impact of their decision on their family (i.e., relationships). Does couple B display a higher level of moral responsibility as a virtue than couple A? Finally, there may be diverging views of one's duties towards one's community, depending on various political and philosophical inclinations. For instance, while couples A and B may have felt a duty towards individuals living with Down syndrome, couple C may be compelled by a perceived duty to decrease the prevalence of Down syndrome in their community. Is couple $\mathrm{C}$ lacking in virtue of moral responsibility?

Gauthier's use of Ronald Dworkin's distinction between "the goal of conformity" and "the goal of responsibility" helps to clarify these questions. What matters for moral responsibility as a virtue to be fulfilled is simply that moral reflection occurs whenever one encounters a situation that presents moral challenges [6]. After deliberation has occurred, moral responsibility dictates that people act freely according to their deliberation, and accept responsibility for their actions, in the retrospective sense "if the goal is responsibility rather than conformity... we must leave citizens free, in the end, to decide what they think right, because that is what moral responsibility entails" [6, p.349]. Therefore, in the context of prenatal testing, I believe that any decision a about whether to test or to terminate a pregnancy would be a "responsive and responsible exercise of self-determination", insofar as it is the result of moral reflection that encompassed perceived implications for individuals, families, communities and societies. 


\section{Conclusion}

I hope to have shown that Gauthier's account of moral responsibility provides conceptual grounds for Press and Browner's idea of a responsibility for expecting couples to consider the social and ethical dimensions of prenatal testing. Further, we have seen that the moral reflection entailed by this responsibility may lead to almost any particular decision regarding prenatal testing. Consequently, it seems fair to conclude that the benefits of the existence of such a responsibility does not lie in any change in prenatal testing rates, as much as in the enhanced quality of the individual decision-making experience. That is, a decision-making process that is characterized by responsibility and responsiveness to one's community, as well as extensive value-based reflection. I wonder if this it what Press and Browner had in mind when they brought up this responsibility notion?

In addition, I wonder how this can apply in real life? Many would point out that the context in which prenatal testing is currently offered does not leave room for this kind of moral reflection. For instance, Rebecca Kukla [17] describes pregnancy as a rather disempowered state in which women submit themselves to the control of others in countless ways (e.g., repeated blood work, lifestyles changes, healthy eating and counting kicks). In this context of medicalization and surveillance, the failure to give moral significance to decisions about prenatal testing described by Press and Browner is to be expected [17]. With this perspective in mind, I ask: is it possible to stimulate the attribution of a social and moral meaning to prenatal testing decisions in order to foster autonomous, responsive, and responsible decision-making, in a medical context that subsumes testing in a normalized pregnancy process? While I do believe that fostering a decision-making process that leaves space for moral responsibility and moral reflection is desirable, I have doubts about whether today's medical culture is prepared for this.

\section{References}

1. Hall A, Bostanci A, Jhon S. Ethical, legal and social issues arising from cell-free fetal DNA technologies; appendix iii to the report: Cell-free fetal nucleic acids for non-invasive prenatal diagnosis. 2009. PHG Foundation.

2. Press N, Browner CH. Risk, autonomy, and responsibility: Informed consent for prenatal testing. Hastings Center Report. 1995; 25 (3 Suppl): S9-12.

3. Vanstone M, King C, de Vrijer B, Nisker J. Non-invasive prenatal testing: Ethics and policy considerations. Journal of Obstetrics and Gynaecology Canada. 2014; 36(6): 515-526.

4. Mansfield C, Hopfer S, Marteau TM. Termination rates after prenatal diagnosis of Down syndrome, spina bifida, anencephaly, and Turner and Klinefelter syndromes: a systematic literature review. European Concerted Action: DADA (Decision-making After the Diagnosis of a fetal Abnormality). Prenat Diagnosis 1999; 19(9):808-12.

5. Newson AJ. Ethical aspects arising from non-invasive fetal diagnosis. Semin Fetal Neonatal Med. 2008; 13(2): 103-108.

6. Gauthier $\mathrm{C}$. Moral responsibility and respect for autonomy: Meeting the communitarian challenge. Kennedy Institute of Ethics Journal. 2000; 10(4): 337-352.

7. Allyse MA, Sayres LC, Havard M, King JS, Greely HT, Hudgins L, Taylor J, Norton ME, Cho MK, Magnus D, Ormond KE. Best ethical practices for clinicians and laboratories in the provision of noninvasive prenatal testing. Prenatal Diagnosis. 2013; 33(7): 656-661.

8. Deans Z, Hill M, Chitty LS, Lewis C. Non-invasive prenatal testing for single gene disorders: exploring the ethics. Eur J Hum Genet. 2013; 21(7): 713-718.

9. de Jong A, Dondorp WJ, de Die-Smulders CE, Frints SG, de Wert GM. Non-invasive prenatal testing: Ethical issues explored. Eur J Hum Genet. 2010; 18(3): 272-277.

10. Norton ME, Rose NC, Benn P. Noninvasive prenatal testing for fetal aneuploidy: clinical assessment and a plea for restraint. Obstet Gynecol. 2013; 121(4): 847-850.

11. Ravitsky V. Non-invasive prenatal diagnosis: an ethical imperative. Nat Rev Genet. 2009; 10(10): 733-733. 
12. Schmitz D, Netzer C, Henn W. An offer you can't refuse? Ethical implications of non-invasive prenatal diagnosis. Nat Rev Genet. 2009; 10(8): 515-515.

13. Schoonen HMHJD, van Agt HME, Essink-Bot ML, Wildschut HI, Steegers EAP, de Koning HJ. Informed decision-making in prenatal screening for Down's syndrome: What knowledge is relevant? Patient Education and Counseling. 2011; 84: 265

14. Eshleman A. Moral responsibility. In The Stanford Encyclopedia of Philosophy. 2014 (Fall 2008 edition)

15. Garcia E, Timmermans DR, van Leeuwen E. Parental duties and prenatal screening: Does an offer of prenatal screening lead women to believe that they are morally compelled to test? Midwifery. 2012; 28(6): e837-843.

16. Savulescu J, Kahane G. The moral obligation to create children with the best chance of the best life. Bioethics. 2009; 23(5): 274-290.

17. Kukla R. Conscientious autonomy: Displacing decisions in health care. The Hastings Center Report. 2005; 35(2): 34-44. 